\title{
THE SPIRITUALITY OF ST BRUNO OF QUERFURT
}

\author{
Fr Rimgaudas Šiūlys
}

ABSTRACT This article analyses the spirituality of St. Bruno of Querfurt, as expressed in his writings. In his Life of the Five Brethren he presents the plan of Otto III to send some of St Romuald's most zealous disciples to the Slavonic countries to build a monastery near the pagan lands. In this way the 'three obligations' seeking the Lord's path, namely: for the new arrivals - the community life they desire, for those mature and seeking the Living God - golden solitude, for those desiring to be free and with Christ - preaching the Gospel to the pagans. We note the following symbols of spiritual life: community life - the monk's habit, golden solitude - the hermitage, preaching the Gospel to the pagans - martyrdom. According to established monastic tradition, before becoming a hermit it is necessary to pass through the stage of community life. The Rule of St. Benedict states that the hermits are "no longer in the first fervour of their reformation, but after long probation in a monastery, having learned by the help of many brethren how to fight against the devil, go out well armed from the ranks of the community to the solitary combat of the desert. They are able now, with no help save from God, to fight single-handed against the vices of the flesh and their own evil thoughts'. The second component of his life is his time as a hermit. For some while St Bruno followed the teaching of St. Romuald, who provided a rule for hermits. First of all, he offered them St. Benedict's Rule, but the Life of the Five Brethren includes the so-called 'Little Rule', which describes the ideal hermit life compactly. The third component is preaching the Gospel - martyrdom. St. Bruno keeps mentioning two things: the preaching of the Gospel and martyrdom. It is thought that his primary goal was martyrdom, and he understood the preaching of the Gospel as a method to attain this goal. With complete sacrifice he begins to preach the Gospel to the pagan nations until finally in 1009 he meets a martyr's death on the border of Lithuania and Rus'.

In very simple terms spirituality is not about what we believe but about how we believe. It would be appropriate at this point to recall the words of St Thomas Aquinas on the Our Father, where he explains the Lord's Prayer as a commentary on the whole of Christian 
life. He arranges the seven pleas of this prayer into three groups, namely: the first two pleas concern our aim to worship God and rejoice in Him; the second two pleas reveal the means by which we may achieve this aim (by obeying God and obtaining bread which represents the whole of what we need for this life); the last three pleas concern removing the obstacles hindering us from achieving our aim, which is God Himself. ${ }^{1}$ Since we try through spirituality to take in and explore what we believe, in this case we are interested in the means, which help us to achieve our end, namely union with God in this life and the next.

Here we come right up against the importance of several of St Bruno of Querfurt's texts and this will determine the structure of the present article. In his Life of the Five Brethren St Bruno writes about the plans of Emperor Otto III to send certain of St Romuald's more zealous disciples into Slav lands in order to build a monastery near pagan territory. This would effect the 'three benefits (commoda) for those seeking the way of the Lord: the community life they desire for those newly arrived from the world; golden solitude for those already mature and desiring the Living Lord; preaching the Gospel to the pagans for those desiring to be released to live with Christ'. ${ }^{2}$ In another place he says that, fortified by the Divine Mercy, Otto III 'desired better things: he burned with great yearning for the three benefits even though one of them would suffice for salvation: the monastic habit, the hermitage and martyrdom'. ${ }^{3}$ Comparing these texts, we see the following stages of spiritual progress: community life, represented by the monastic habit; solitude represented by the hermitage, and martyrdom in the form of preaching the Gospel to the pagans. Although seeking these three benefits is portrayed as the idea of Otto III, J. Leclercq noted that these stages (community life, eremitic life and preaching the Gospel) are not the agenda of that age

${ }^{1}$ St Thomas Aquinas, Summa Theologiae, Secunda pars secundae partis, quaestio 83, articulus 9.

2 Bruno of Querfurt, 'Vita quinque fratrum' [VQF] 2, in: Monumenta Poloniae Historica, VI (Warsaw, 1961), pp. 392-393: 'tripla commoda querentibus viam Domini, hoc est noviter venientibus de seculo desiderabile cenobium, maturis vero er Deum vivum sicientibus aurea solitudo, cupientibus dissolvi et esse cum Christo euangelium paganorum'.

${ }^{3}$ VQF 7, pp. 400-401: 'meliora volebat, qui etiam tria maxima bona, quorum unum ad salutem sufficit, monachicum habitum, heremum et martyrium toto desiderio ardebat'. 
or St Romuald but the personal belief of St Bruno. ${ }^{4}$ Or rather, the first two spiritual benefits reflect the charisma of St Bruno's teacher, St Romuald and are rooted in earlier monastic tradition. We may attribute the inclusion of the third benefit in this list either to Otto III or St Bruno but this also had a long tradition which reached $\mathrm{St}$ Bruno via its famous representatives St Gregory the Great and $\mathrm{St}$ Augustine of Canterbury, St Boniface and St Wojciech-Adalbert. ${ }^{5}$

Now we may look in detail at each of the three spiritual benefits separately. The first is community life. According to established monastic tradition, a monk must first live in community before taking on the eremitic life. St Benedict's Rule says that hermits may be those "no longer in the first fervour of their reformation, but after long probation in a monastery, having learned by the help of many brethren how to fight against the devil, go out well armed from the ranks of the community to the solitary combat of the desert. They are able now, with no help save from God, to fight single-handed against the vices of the flesh and their own evil thoughts'. ${ }^{6}$ The monastic condition is connected closely with friendship. According to St John Cassian (considered to have introduced eastern monastic practices to the West), the monastic condition is institutionalized friendship. ${ }^{7}$

St Bruno entered the Benedictine cloister in 998. He chose Boniface as his name in religion and in 999 he joined St Romuald's eremitic movement. G. Tabacco says that close ties of friendship developed within St Romuald's inner circle. ${ }^{8}$ One monk, Benedict of Benevento enjoyed Romuald's special confidence, as St Bruno says: 'the master, Romuald, praised Benedict very highly for being like a rock during fasts and vigils; and he rightly praised him to me and everyone wonderfully for his proper obedience and chaste manners, in which, as God is our witness, he lived

${ }^{4}$ J. Leclercq, 'San Romualdo e il monachesimo missionario', idem, Momenti e figure di storia monastica italiana (Cesena, 1993), p. 273.

5 J. Wong, 'Il triplex bonum nella vita dei primi discepoli di s. Romualdo', San Romualdo (San Piero in Cariano, 2003), pp. 271-272.

${ }^{6}$ Rule of St Benedict, Chapter One, 3-5 (in the Lithuanian translation - Šventojo Benedikto regula (Vilnius, 1997), p. 21).

${ }^{7}$ L. Pizzolato, L'idea di amicizia nel mondo antico classico e cristiano (Turin, 1993), pp. 327-328, 332.

${ }^{8}$ G. Tabacco, Spiritualità e cultura nel Medioevo (Naples, 1993), p. 170. 
delightfully'. ${ }^{9}$ The time would come when Romuald would wish him to become abbot: 'from the time when the Spirit of God taught [Romuald] to discern character he found none more suitable for this task than Benedict, of whom it is said "in his heart thoughts of the kingdom of heaven resided" ". ${ }^{10}$ Thus it is no surprise that St Bruno was entrusted to his care and that ties of friendship developed between Bruno and Benedict. In his Life of the Five Brethren this tie is described in terms of close friendship: 'the privilege of charity' (privilegium amoris), 'a sign of love' (signum amoris), 'a pledge of love' (pignus amoris). ${ }^{11}$ These terms deriving from a feudal and imperial context express a close connection and have a much stronger meaning than may at first seem to be the case; privilegium amoris is not a new phrase but it was quite rare until the eleventh century. Most often it is used to refer to the special relationship between Our Lord and St John the Evangelist and thus it is chosen here to reflect the exceptional connection between Bruno and Benedict in a clear Christological context. ${ }^{12}$

St Bruno sets about persuading Benedict to accompany him to the lands of the Slavs to spread the gospel and resolve to die for Christ: 'I, whom as a special token of love he used to call my brother', would suggest each hour to blessed Benedict that he travel to Slavonic climes to preach the gospel, saying I was ready to help in this matter. "It is a dangerous place", I say, "it is an unwelcoming slough. Who does not fall ill here, from the least to the highest? And yet, as properly a sign from God, none dies from such sickness. What work in the cell, I ask, do the hands of him do, whose feet, come Sunday, cannot seek Holy Communion in church?"'. ${ }^{13}$ These

${ }^{9}$ VQF 2, 391: 'Hunc Benedictum ita laudavit magister Romualdus, ut in ieiuniis et vigiliis quasi saxum esse affirmaret; et propter innocentiam obedienciae et castitatem morum, in quibus teste Deo delectabiliter ambulavit, merito eum mihi et omnibus mirabiliter predicavit'.

${ }^{10}$ VQF 2, 393: 'Neminem vero ad hoc opus - ut in discernendis personis spiritus Dei ipsi inerat - meliorem invenit quam Benedictum, de quo dictum est: In cuius pectore cogitationes caeli civitatem posuerunt'.

${ }^{11} \mathrm{VQF} 2$, p. 394; 4, p. 396; 5 p. 397.

${ }^{12}$ L. Saraceno, 'L'amicizia spirituale: un tratto del carisma romualdinocamaldolese', Il carisma nel seculo XI Genesi, forme e dinamiche istituzionali, Atti del XXVII Convegno del Centro di studi avellaniti (San Piero in Cariano, 2006), p. 170.

${ }^{13} \mathrm{VQF}$ 2, 394: 'Ego autem, quem pro privilegio amoris "frater meus" appellare solebat, inter horas beato Benedicto suggerebam, ut in Sclavoniae partes causa 
arguments convince Benedict. R. Forniciari asserts that the German monk broke the fine connection between Romuald the master and his disciple Benedict. At first he talked him out of agreeing to become abbot of Pereum and now he talks him into taking part in a mission and leaving his master for good. ${ }^{14}$ This also shows Benedict's weakness of character. Instead of becoming the leader of Bruno's monastic life, he becomes someone who is himself led. Clearly Bruno was superior because he enjoyed close relations with Emperor Otto III.

In one way or another, a mission with the prospects of martyrdom united Bruno and Benedict. We can see this from Bruno's words in his farewell speech: 'then I say "I beseech you most sweetly, my brother, through our common hope, Christ Jesus, Son of the Virgin, remember that you have me with you and you with me. When you pray or sing the psalms, always pray and beg the Living God that for His name's sake He grant the desire which He has given us both, that before we die you and I, a sinner, may, through the Divine Mercy, see the happy day when through shedding our blood we may obtain from the hand of God remission of all our sins", 15

Benedict and Brother John go to Poland and set up a convent there with the aid of Duke Bolesław. They are joined by several local men. Bruno does not go with them but remains behind in Italy to obtain papal permission to lead a mission and, after obtaining this, he intends to join up with his brethren.

euangelizandi perrexisset, asserens, me ipsum in hoc opus esse paratum. „Infestus“, inquio, „locus et inimica palus hec est. A minimo usque ad summum quis iam hic non infirmatur? et ita, ut proprie Dei signum sit, in tanta infirmitate ne quis moriatur. Qualia, queso, in cella opera manus eius faciunt, cuius pedes, cum venerit domenica, sacrum communionem in ecclesia querere non poterunt?'.

${ }^{14}$ R. Fornaciari, 'Romualdo di Ravenna, I suoi discepoli Benedetto di Benevento e Giovanni e il monachesimo missionario dell'età ottoniana', Ottone III e Romualdo di Ravenna. Impero, monasteri e santi asceti". Atti del XXIV Convegno del Centro Studi Avellaniti, Fonte Avellana 2002, (San Piero in Cariano 2003), p. 255

${ }^{15}$ VQF 5, p. 397: "tunc: "Dulcissime“, inquio, "freter meus, rogo te per communem spem, Ihesum Christum, virginis filium, memento, quod me tecum et te mecum habere nosti. Cum oras aut psallis, semper precare et obsecra Deum vivum, ut, quod dedit ambobus, desiderium unum perficiat propter nomen suum, nec prius moriamur, quam et tu et ego peccator videamus in misericordia Dei felicem diem, scilicet fuso sanguine per rationem, in digito Dei remissionem omnium peccatorum". 
Such were his intentions, but what was the reality? St Bruno delayed his journey to Rome and after obtaining papal permission for their venture and setting off for Germany he never caught up with his fellow missionaries. Bandits killed the brethren, who had settled in Poland on 11 November 1003.

Now we must take a closer look at Bruno's Life of the Five Brethren (in all five men were slain: Benedict, John, two Polish novices and their cook). Leclercq thinks that this is no ordinary mediaeval hagiography but an account of martyrdom. ${ }^{16}$ However, P. Tomea delves deeper into the story to uncover that the main actor here is the author himself, who had laid the way open for the death of Benedict and John and so this opus is a touching autobiographical sketch concerning St Bruno, which reveals his tormented conscience with regard to the trust Benedict had placed in him. ${ }^{17}$ Bruno says that the brothers were surprised that he did not arrive with the papal licence and accused him of carelessness and lying because they would not have gone there if he had not convinced them to do so and gained the support of Otto III for this idea. ${ }^{18}$ Therefore it is completely understandable why in the speech which eventually overcomes Benedict's opposition Bruno refers to himself as the 'son of carelessness' (filius negligentiae). ${ }^{19}$ Finally, having mentioned the death which threatens them, Bruno lashes himself with such words: 'it was not worthy for me, a dog, to approach the saints, for me, a swine, to approach the pearls; this [accusation] was no insult for I refused to go to them who awaited me in such tribulation so many days and nights as a saint with the saints, a chosen one with the elect; I was a wretched and woeful Sarabaite, ${ }^{20}$ doing my own will, a prickly hypocrite in my vain glory'. ${ }^{21}$

${ }^{16}$ Leclercq, 'San Romualdo', p. 260.

${ }^{17}$ P. Tomea, 'La colpa e il martirio', San Romualdo, [as n. 5], p. 193.

${ }^{18}$ VQF 9, p. 402.

${ }^{19} \mathrm{VQF}$ 3, p. 395.

${ }^{20}$ Sarabaite - a monk who does not live by a Rule, regarding what pleases him as holy and what does not, as unlawful; they are worse even than the wandering gyrovague - Rule of St Benedict, Chapter One, 6-12.

${ }^{21} \mathrm{VQF}$ 10, p. 404: 'et me canem ad sanctos et me porcum ad margaritas venire dignum non erat, non iniuria, quia nolui venire ad eos, qui me expectaverunt cum tanta tribulatione, tot dies, tot noctes, cum sanctis sanctus, cum electis electus, quin potius esse ut miser et miserabilis sarabaita in propria voluntate et spinosus hypocrita in vana gloria'. 
Thus St Bruno's first opus takes on a specific and unexpected form. What is common to many monks, namely community life and friendship, is mixed up with carelessness to the point of treachery. This will not go unnoticed. God is so mighty and good that He can derive good from evil, ${ }^{22}$ and so all that we encounter in life forms a complete whole and should help us obtain our main aim, namely to be with God. We shall see how this works out in Bruno's life.

Bruno's second area of activity is the life of a hermit. At first Bruno followed St Romuald in the monastic life according to the rule the saint composed for hermits. First of all he suggested they follow St Benedict's Rule and a 'Small Rule' is set down in the Life of the Five Brethren. Here, according to J. Wong, the ideal of a hermit's life is described here in detail. ${ }^{23}$ This text says: 'Sit in your cell as if you were in heaven; put behind you all memory of the world and take care of your thoughts like a good fisherman takes care of his fish. One way [to your goal] lies in the psalms and this you should not leave. If you cannot do everything you conceived in fervour as a novice, sing psalms in your spirit here one time, there at another time and try to understand the texts mentally; when you begin to wander in your reading, do not give up but hasten to improve in understanding; place yourself before all things in the presence of God with awe and trembling as one who stands in the presence of the emperor; abase yourself completely and sit like a babe, who knows not what to eat nor has any food, if its mother does not feed it, and be thus content on the grace of God'. ${ }^{24}$

It is known that St Romuald based his spiritual teaching on the work of St John Cassian and the text under examination here conforms nicely with the desert monastic tradition. ${ }^{25}$ Essentially he

${ }^{22}$ Catechism of the Catholic Church, 311: For almighty God..., because He is supremely good, would never allow any evil whatsoever to exist in His works if $\mathrm{He}$ were not so all-powerful and good as to cause good to emerge from evil itself.

${ }^{23}$ Wong, 'Il triplex bonum', p. 257

${ }^{24}$ VQF 32, p. 427: 'Sede in cella quasi in paradise; proice post tergum de memoria totum mundum, cautus ad cogitationes, quasi bonus piscator ad pisces. Una via est in psalmis; hanc ne dimittas. Si non potes omnia, qui venisti fervore novicio, nunc in hoc, nunc illo loco psallere in spiritu et intelligere mente stude, et cum ceperis vagari legendo, ne desistas, sed festina intelligendo emendare; pone te ante omnia in presentia Dei cum timore et tremore, quasi qui stat in conspectu imperatoris; destrue te totum et sede quasi pullus, contentus ad gratiam Dei, qui, nisi mater donet, nec sapit nec habet quod comedat'.

${ }^{25}$ VQF 2, p. 390; Wong, 'Il triplex bonum', pp. 257-26. 
shows us how to read the Psalter, to meditate and to pray. There are different levels of spiritual activity: lectio, meditatio, oratio. ${ }^{26}$

The third area of action is preaching the Gospel - martyrdom. Now we must examine certain other facts of the saint's life. At the age of twelve he began to attend the cathedral school in Magdeburg, which was one of the most important centres of learning in Saxony. Later he was ordained priest and appointed canon in the same city. Here a desire arose among the clergy to spread the gospel among the Slavs. ${ }^{27}$ Finally in 995 Otto III appointed Bruno as his court chaplain. In 997 St Wojciech-Adalbert met a martyr's death in Prussia. This martyrdom had a great impact not only on the imperial court at large but also on Bruno himself and later he composed a separate opus devoted to the new martyr. ${ }^{28}$ In 998 Bruno entered a Benedictine monastery and a year later became a disciple of St Romuald but he did not break his close contacts with Otto III. The emperor, Romuald and Bruno drew closer. Otto III even promised to become a monk himself later. There was an intention to build a monastery on the border between Christendom and pagan lands to spread the Gospel and seek martyrdom. The source of this idea was St Bruno. ${ }^{29} \mathrm{He}$, or the emperor, did indeed do much to put this plan into action, but St Romuald declined to take part in it. ${ }^{30}$

St Bruno lays stress on two things, namely preaching the gospel to pagans and martyrdom. What then connects these two? Leclercq considers that his primary aim was martyrdom and that preaching the gospel was something he regarded as a means to achieving this end. ${ }^{31}$ Other scholars, it seems, are inclined to favour this view. ${ }^{32}$ It is quite hard to determine Bruno's aims since from the very first days of Christianity believers have been forbidden to seek martyrdom deliberately. This cannot be an end in itself but only a means for bearing witness to the Faith under certain circumstances. Admittedly, in his Life of the Five Brethren Bruno already answers

${ }^{26}$ Ibid., p. 262.

${ }^{27}$ R. Fornaciari, 'I cinque Fratelli martiri (†1003)', Vita monastica, 230 (2005), p. 72 .

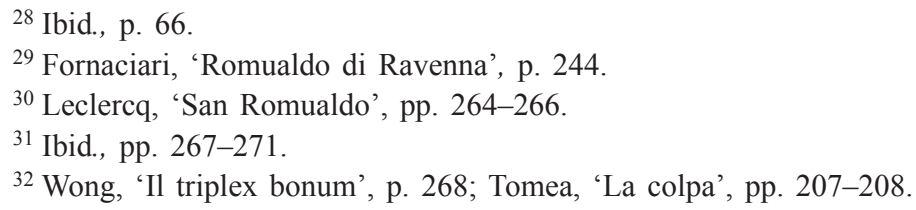


the criticism that it is vanity for sinners to seek martyrdom, but his answer does not remove the difficulty. ${ }^{33}$ Also we must not overlook the fact that the style of mediaeval literature may have affected the extreme nature of Bruno's manner of expression. ${ }^{34}$ We have no space to resolve this issue here. We may only add that St Bruno achieved most in his community and eremitic life by developing this third area of action. ${ }^{35}$

The aim of this study was to examine St Bruno of Querfurt's spirituality as a whole set of means which led him into closer union with God. First of all this was his community life in the context of which close friendship developed between him and his fellow monk, Benedict. Our Lord and His beloved disciple, St John, form the model for this friendship. Secondly we see his life as a hermit, typified by ancient traditions of prayer. Thirdly he sought to preach the gospel albeit perhaps with an exaggerated yearning for martyrdom. However, unexpected things intertwine with these tools for the spiritual life and they are typical only of our saint. $\mathrm{He}$ did not keep his word to Benedict and the latter perished without seeing his brother again. A feeling of guilt marked Bruno's life and it seems this encouraged him to further action: he did not abandon his plans and devoted himself completely to preaching the gospel to the Nations until finally in 1009 he met a martyr's death on the border between Lithuania and Rus'.

Translated by S.C. Rowell

Author Details

Fr Rimgaudas Šiūlys holds a Licentiate in Theology and is spiritual director and lecturer at St Joseph`s Seminary in Vilnius. His main area of research is the theology of spirituality.

Address: Vilniaus Šv. Juozapo kunigų seminarija, Kalvariju g. 325, LT-08420 Vilnius

Email: rimgaudui@gmail.com

${ }^{33}$ VQF 2, p. 394.

${ }^{34}$ Fornaciari, 'Romualdo di Ravenna', p. 266.

${ }^{35}$ Fornaciari, 'I cinque Fratelli', pp. 68-71. 


\title{
ŠV. BRUNONO KVERFURTIEČIO DVASINGUMAS
}

\author{
Santrauka
}

\section{RIMGAUDAS ŠIULLYS}

Dvasingumo sąvoka nusako ne tai, kuo mes tikime, bet - kaip tikime. Kadangi dvasingumu stengiamasi aprèpti ir nagrinèti tai, kaip tikime, šiuo atveju mus ir domina priemonès, padedančios eiti tikslo link - siekti vienybès su Dievu tiek šiame, tiek būsimajame gyvenime.

Čia iš karto iškyla kelių šv. Brunono Kverfurtiečio parašytų tekstų svarba. Jie lemia viso šio straipsnio struktūrą. Savo veikale Penkiu broliu gyvenimas jis rašo apie imperatoriaus Otono III sumanymą siųsti uolesnius šv. Romualdo mokinius ị slavų kraštus netoli pagoniškų žemių statydintis vienuolyną. Šitaip būtų parūpintos „trys vertybès (commoda) ieškantiems Viešpaties kelio - būtent: naujai atèjusiems iš pasaulio - trokštamas bendruomeninis gyvenimas; jau subrendusiems ir trokštantiems Gyvojo Dievo - auksinè vienuma; trokštantiems būti išvaduotiems ir būti su Kristumi - Evangelijos skelbimas pagonims. " Kitoje vietoje sakoma, kad Otonas III, Dievo gailestingumo sustiprintas, ,troško geresnių dalykų - degė dideliu troškimu trijų aukštesnių gèrybių - vienuolinio abito, eremo ir kankinystès, nors ir vienos iš jų pakaktų išganymui." Palyginę tekstus, matome tokias dvasinès veiklos pakopas: bendruomeninis gyvenimas - vienuolinis abitas; vienuma - eremas; Evangelijos skelbimas pagonims - kankinyste. Nors šių triju gèrybių seka pateikiama kaip Otono III sumanymas, tačiau, pasak J. Leclercqo, šios bendruomeninio gyvenimo - atsiskyrèliško gyvenimo - Evangelijos skelbimo pakopos nẻra nei ano meto, nei šv. Romualdo programa, būtent tai yra asmeninis šv. Brunono Kverfurtiečio isitikinimas. Tiksliau kalbant, pirmosios dvi gèrybès atspindi šv. Brunono mokytojo šv. Romualdo charizmą ir ịsišaknijusios dar ankstyvesnèje vienuolinejje tradicijoje. Trečiosios gèrybės iškẻlimą galima priskirti arba Otonui III, arba pačiam šv. Brunonui, tačiau ir jos tradicija sena.

Vis dẻlto šv. Brunono atveju į šiu gėrybių seką issipina ir nenumatytų dalykų, būdingų tik šiam šventajam. Jis neišpildo savo pažado, duoto Broliui Benediktui, ir šis žūva nesulaukęs savo bičiulio. Kaltè paženklina šv. Brunono gyvenimą, ir atrodo, ji skatina ji eiti pirmyn: jis neišsižada savo plano ir visiškai atsidavęs pradeda skelbti Evangeliją pagonių tautoms, kol galiausiai 1009 m. sutinka kankinio mirti Lietuvos ir Rusijos žemiu pasienyje. 